\title{
Estimation of Coal and Rock Mechanical Properties for Numerical Modelling of Longwall Extraction
}

\author{
Tien Dung LE ${ }^{1, *)}$, Chi Thanh NGUYEN ${ }^{2)}$, Van Chi DAO
}

\footnotetext{
1) Department of Underground Mining, Hanoi University of Mining and Geology, Hanoi, Vietnam; email: t.d.le@humg.edu.vn; daovanchi@humg.edu.vn

2) Department of Underground Construction and Mining, Hanoi University of Mining and Geology, Hanoi, Vietnam; email: nguyenchithanh@humg.edu.vn
}

http://doi.org/10.29227/IM-2020-02-07

Submission date: 06-03-2020 | Review date: 22-09-2020

\section{Abstract}

Reliable estimation of coal and rock mechanical properties at field scale is a prerequisite for numerical modelling of rock behaviours associated with longwall extraction. This paper describes a systematic approach from data collection, laboratory testing to rock mass properties derivation for simulation of longwall extraction, taking two longwall panels at Quang Ninh coalfield in Vietnam for example. The mechanical properties are verified through comparison with published data of the field, indicating close agreements. A simple numerical model is further developed to demonstrate the proper use of the obtained data. The simulation suggests that the ratio of model length to excavation length should be in the range of 2.5-5; uniaxial compressive strength, deformation modulus and tensile strength can be reduced by a factor of 5.0, 2.13 and 2.0, respectively; and a calibration and validation process must be performed to match in-situ longwall's behaviours. The approach can be applied for derivation of reliable rock mass properties for numerical simulation of underground excavations.

Keywords: laboratory test, rock mass properties, strength reduction, field scale modelling

\section{Introduction}

Longwall mining has been widely applied around the world due to its high production and reduced development cost compared to other underground extraction methods. The successful operation of this technology is greatly dependent on the understanding of major geotechnical issues associated with the advance of longwall face. Because geological and mining conditions are diversified and complex, for example, thick and flat moderate coal seams in Australia to thin and steep weak coal seams in Vietnam, geotechnical issues can be greatly different as well. Numerical modelling, as an analysis tool based on mathematical equations calculating via computer, has been broadly used in studying longwall geotechnical issues within limited time and/or budget. Since rock mechanics are "data-limited problems" that cannot be modelled unambiguously as emphasized in many studies for decades (Starfield and Cundall, 1988, Wiles, 2006, Alejano et al., 2008, Galvin, 2016, Itasca Consulting Group, 2019), a reliable estimation of available input rock properties should, therefore, reduce uncertainties resulted from numerical assumptions and/or simplifications in longwall simulation. Fundamental insight into practical problem mechanics can be accordingly discovered.

Because longwall-associated geotechnical problems often occur in large/field scale, input rock properties for the modelling must be of representativeness at the field scale. It is important to note that large-scale physical testing of rock material is normally limited to a certain scale due to high cost (Elmo et al., 2009, Itasca Consulting Group, 2019). Thus, a more common approach is to derive intact rock properties from laboratory scale before reducing them to field scale for the inclusion of impact of micro- and macro-fractures on ma- terial response. In the literature, various techniques for scaling of rock properties from laboratory to large scale have been developed and classified into four main approaches (Deisman et al., 2010, Coggan et al., 2012, Gao and Kang, 2016). In the first approach, intact rock properties from standard laboratory test are scaled by using an empirical reduction factor. This approach was suggested by Wilson (1983) for UK coal measures and has been extended to general coal measures rock (McNally, 1996). For the second approach, Hoek-Brown (HB) failure criterion combined with Geological Strength Index (GSI) are combined to reduce intact properties to rock mass properties (Hoek and Brown, 1997). This approach can work adequately with poor quality rock mass such as coal measures owing to the use of GSI. The third approach is to use Synthetic Rock Mass (SRM) (Pierce et al., 2007), whereby a synthetic rock mass composed of intact rock and discrete fracture network is modelled for strength or deformation simulation tests. The final approach involves the use back analysis (Sakurai, 1993) of stress-strain relationship measured at the field. In general, various scaling techniques all find their applications in studying longwall mining, depending on time and budget available.

This paper aims to develop a simple and efficient approach for reliable estimation of coal and rock properties for numerical modelling of longwall extraction. Data collection, laboratory testing and rock mass properties derivation are described using geological conditions from two longwall panels at Quang Ninh coalfield, Vietnam. A simple discrete element model is further developed to demonstrate the proper use of the obtained properties. The approach can be applied for derivation of reliable rock properties for numerical simulation of underground excavations. 


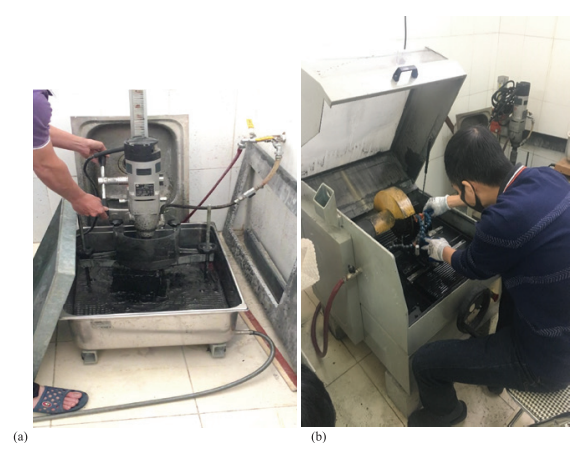

Fig. 1. (a) Coring machine, (b) Trimmer and cut-off machine Rys. 1. (a) Maszyna rdzeniowa, (b) Przycinarka i przecinarka

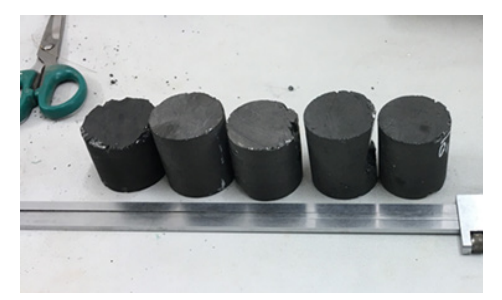

Fig. 2. Result of sample preparation Rys. 2. Wynik przygotowania próbki

Tab. 1. Results of unconfined compression test for coal and rock at Ha Lam and Vang Danh coal mines Tab. 1. Wyniki próby swobodnego ściskania węgla i skał w kopalniach Ha Lam i Vang Danh

\begin{tabular}{|l|c|}
\hline Sample type & $\begin{array}{c}\text { Unconfined compressive } \\
\text { strength (MPa) }\end{array}$ \\
\hline Ha Lam coal & 15.45 \\
\hline Ha Lam rock & 46.9 \\
\hline Vang Danh coal & 26.89 \\
\hline Vang Danh rock & 89.39 \\
\hline
\end{tabular}

\section{Sample collection and preparation Sample collection}

Raw samples of coal and rock are designed to collect at fully mechanized longwall faces in Ha lam and Vang Danh coal mines. The two mines represent two typical coal seam strengths at Quang Ninh coalfield that are weak and moderate seams, respectively. At each face, at least nine coal blocks in the dimension of $20 \times 20 \times 20 \mathrm{~cm}$ are collected at the two gate ends and middle of longwall face. The block must contain no or sparse discontinuities which can be visibly observed. Rock samples are similarly collected at immediate roof or development roadway. The raw samples are transported out of the face and carefully stored in laboratory condition.

\section{Sample preparation}

The sample preparation equipment is manufactured by Controls S.p.A (2020). The coring machine coded 45-C0330 (Figure 1a) with coring speed of $1485 / 2720 \mathrm{rpm}$ and coring range of $8-60 \mathrm{~mm}$ is used to extract cylindrical samples of approximately $42 \mathrm{~mm}$ diameter. The two ends of the core sample are trimmed by core trimmer and cut-off machine coded 32-D0536, which has a blade speed of $3000 \mathrm{rpm}$ (Figure 1b). Several complete core samples are shown in Figure 2.

\section{Laboratory tests \\ Unconfined compression test}

The unconfined compression test is implemented by using ADVANTEST 9 ROCK-a servo-hydraulic control con- sole for axial load applications such as loading-unloading ramps and load/stress/displacement/strain-controlled tests (Figure 3). Main technical specifications of the console are power rating of $780 \mathrm{~W}$; maximum working pressure of 700 bar; maximum oil delivery of $0.7 \mathrm{lpm}$ at high pressure or 2.0 $\mathrm{lpm}$ at low pressure; four hydraulic ports for connection of test frames; and flow control via a servo-controlled proportional valve. Accessories include remote control, high stiffness compression frame, compression device, strain gauge and PC.

The test procedure includes measuring sample diameter and height, placing sample onto the centre of lower platen and lowering top platen in good contacts, and continuously loading sample with a constant rate of $0.7 \mathrm{MPa} / \mathrm{sec}$ until failure. The complete test results are summarised in Table 1.

\section{Shear test}

The shear test is also carried out by using ADVANTEST 9 ROCK and clamping frames for testing at 45 and 60 degrees (Figure 4a). The procedure is as follows: measuring sample diameter and height; placing a sample in between two clamping frames and leaving a gap of 3-4 mm between frame interfaces; continuously loading top frame with a constant rate of $0.7 \mathrm{MPa} / \mathrm{sec}$. The peak load when the sample fails is recorded (Figure 4b). Each rock type is tested 2-3 times for each angle of 45 and 60 degrees. Shear stress and normal stress are calculated in Equations 1-2 where P is peak load at failure, $S$ is a shear area, $\alpha$ is the angle of the shear test, $\phi$ is internal 


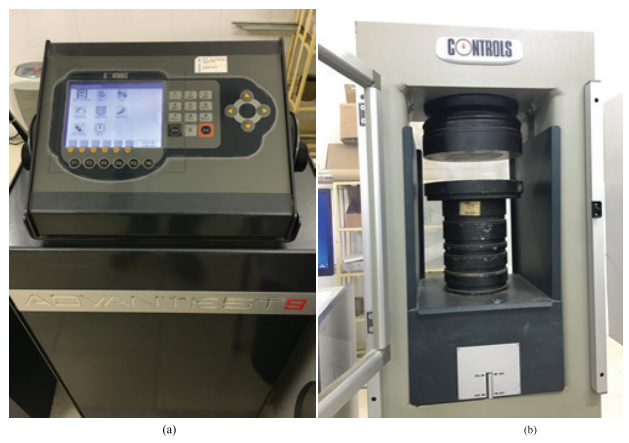

Fig. 3. Advantest 9 rock

Rys. 3. Advantest 9 rock

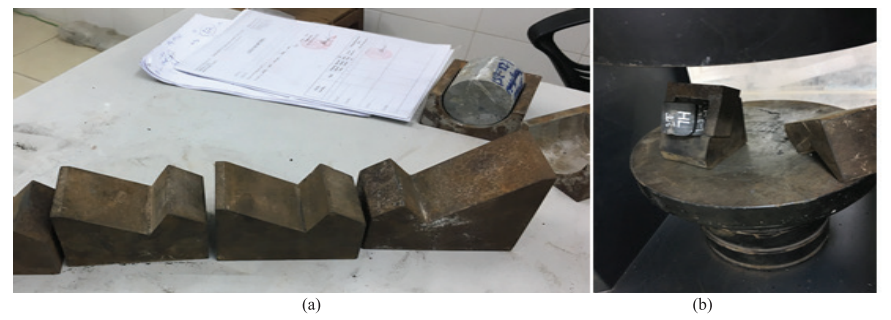

Fig. 4. (a) Clamping frames, (b) Sample failed in shear test

Rys. 4. (a) Ramy zaciskowe, (b) Próbka uszkodzona z testu ścinania

Tab. 2. Results of shear test for coal and rock at Ha Lam and Vang Danh coal mines

Tab. 2. Wyniki próby ścinania węgla i skał w kopalniach Ha Lam i Vang Danh

\begin{tabular}{|c|c|c|c|c|}
\hline Sample type & $\begin{array}{c}\text { Averaged shear strength } \\
\text { (MPa) }\end{array}$ & $\begin{array}{c}\text { Averaged normal strength } \\
\text { (MPa) }\end{array}$ & Cohesion (MPa) & $\begin{array}{c}\begin{array}{c}\text { Internal friction angle } \\
\text { (degree) }\end{array} \\
\end{array}$ \\
\hline $\begin{array}{l}\text { Ha Lam coal } \\
\text { (45 degrees) }\end{array}$ & 10.09 & 10.09 & \multirow{2}{*}{5.36} & \multirow{2}{*}{ ( } \\
\hline $\begin{array}{l}\text { Ha Lam coal } \\
\text { (60 degrees) }\end{array}$ & 7.34 & 4.24 & & \\
\hline $\begin{array}{l}\text { Ha Lam rock } \\
\text { (45 degrees) }\end{array}$ & 23.74 & 23.74 & \multirow{2}{*}{11.60} & \multirow{2}{*}{27.10} \\
\hline $\begin{array}{l}\text { Ha Lam rock } \\
\text { (60 degrees) }\end{array}$ & 16.46 & 9.50 & & \\
\hline $\begin{array}{l}\text { Vang Danh coal } \\
\text { (45 degrees) }\end{array}$ & 10.71 & 10.71 & \multirow{2}{*}{6.74} & \multirow{2}{*}{20.33} \\
\hline $\begin{array}{l}\text { Vang Danh coal } \\
\text { (60 degrees) }\end{array}$ & 9.93 & 8.60 & & \\
\hline $\begin{array}{l}\text { Vang Danh rock } \\
\text { (45 degrees) }\end{array}$ & 45.13 & 45.13 & \multirow{2}{*}{9.65} & \multirow{2}{*}{38.19} \\
\hline $\begin{array}{l}\text { Vang Danh rock } \\
\text { (60 degrees) }\end{array}$ & 17.67 & 10.20 & & \\
\hline
\end{tabular}

frictional angle and $\mathrm{C}$ is cohesion. The complete test results are given in Table 2 .

$$
\begin{aligned}
& \tau=P \sin \alpha / S \\
& \tau=\sigma \tan \varphi+C \\
& \sigma^{t}=2 P_{\max } / \pi D t
\end{aligned}
$$

\section{Indirect tensile test}

Indirect tensile test (or Brazilian test) is recommended by the International Society for Rock Mechanics (ISRM) as a standard test for determination of tensile strength of a material. Using ADVANTEST 9 ROCK, the sample is loaded along its generating line through a half-ball bearing, as seen in Figure 5. The sample is continuously loaded with a constant rate until it fails. Indirect tensile stress is perpendicularly formed in the loading direction. Tensile strength is calculated in Equation 3 where $\mathrm{P}_{\max }$ is peak load at failure, $\mathrm{D}$ is sample diameter, and $t$ is sample thickness. The complete test result is shown in Table 3. Note that there is no complete test for $\mathrm{Ha}$ Lam samples due to their very weak strength.

\section{Modelling of longwall extraction}

This section demonstrates step by step the use of laboratory test data for simulation of longwall extraction. A two-dimensional discrete element code named UDEC (Itasca Consulting Group, 2019) is employed. As a longwall panel is commonly large in strike direction and small in dip direction, a vertical cross-section at the centre of panel in strike direction is modelled in plane-strain condition. Depending on the excavation length to be modelled, the model boundaries should be sufficiently far away from the area of interest to minimize the impact of the truncate boundary. For instance, a ratio of model length 11 to excavation length 12 can vary from 2.5 (Singh and Singh, 2009) to 5.0 (Le et al., 2018). The overburden strata above the coal seam may be explicitly modelled to some extent and should be able to enable their periodic movements. The detail level of geological structures is normally decreased from the area of interest to outer area, but representative structures must be adequately incorporated. Model geometry for a longwall face at Ha Lam coal mine is outlined in Figure 6.

It is important to define constitutive laws for rock mass in the model before associated material properties can be assigned. In the current model, plastic and Coulomb Slip laws 
Tab. 3. Result of indirect tensile test for coal at Vang Danh coal mine

Tab. 3. Wynik próby pośredniego rozciągania węgla w kopalni Vang Danh

\begin{tabular}{|l|c|}
\hline Sample type & Tensile strength (MPa) \\
\hline Vang Danh coal & 2.7 \\
\hline
\end{tabular}

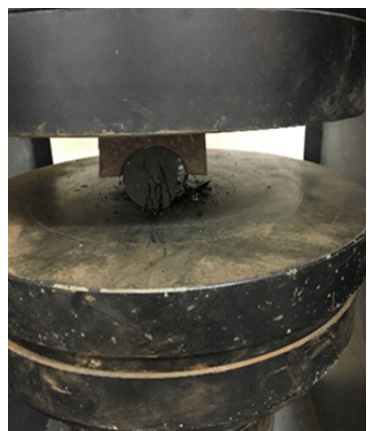

Fig. 5. Indirect tensile strength test

Rys. 5. Badanie wytrzymałości na rozciąganie pośrednie

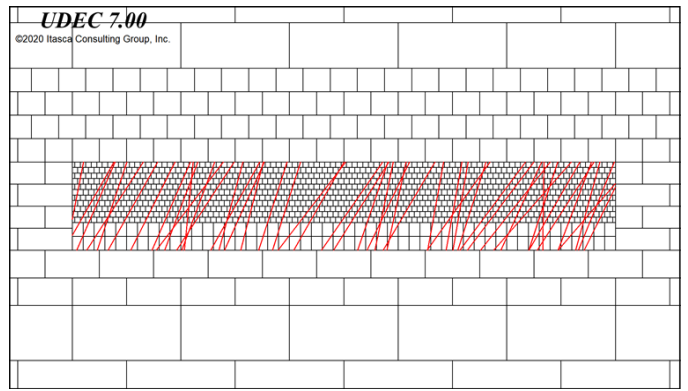

Fig. 6. Model geometry of Ha Lam coal face

Rys. 6. Geometria modelu czoła węglowego Ha Lam

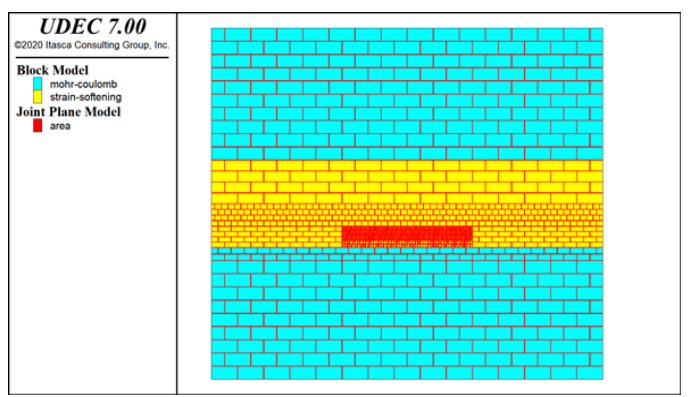

Fig. 7. Constitutive laws for intact blocks and discontinuities

Rys. 7. Prawa konstytutywne dla nienaruszonych bloków i nieciągłości

are assigned to intact blocks and discontinuities, respectively (Figure 7). These laws are capable of representing key failure mechanisms of rock mass in longwall extraction. Since no test for discontinuity properties is available, the properties are assumed to be similar to those in previous longwall studies. Because block size in the model is significantly greater than that in the laboratory test for computation efficiency, its properties must be in field scale. These properties are derived from laboratory scale and take into account the impact of small fractures. In cases where confined compression test and/or GSI is not available, the approach using a reduction factor can be used. For coal measures rock, uniaxial compressive strength, deformation modulus and tensile strength are reduced by a factor of 5.0, 2.13 and 2.0, respectively, (McNal- ly, 1996, Mohammad et al., 1997). It is noted that as UDEC (and also other numerical programs) uses internal friction angle and cohesion strength to represent material strength, and these parameters should be carefully selected to match the scaled-tested strength (Figure 8). The residual parameters, as unavailable, are adapted from past numerical coal studies. The pre-mining vertical stress is equal to horizontal stress in all modelled strata, although a discrepancy may occur in coal seam as noted by Sheorey (1994). Finally, due to the above assumptions regarding unknown parameters, a calibration and validation process must be performed to match in-situ longwall issue's behaviours such as rock mass displacement or stress redistribution. Figure 9 displays a calibrated model for the purpose of studying face spall in a longwall extraction. 


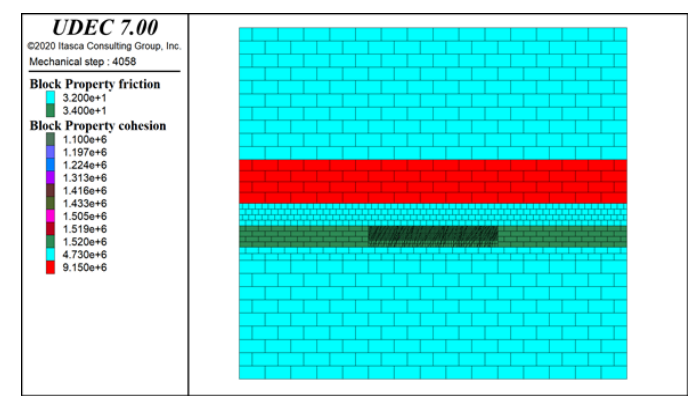

Fig. 8. Block friction angle and cohesion strength Rys. 8. Kąt tarcia wewnętrznego bloku i siła kohezji

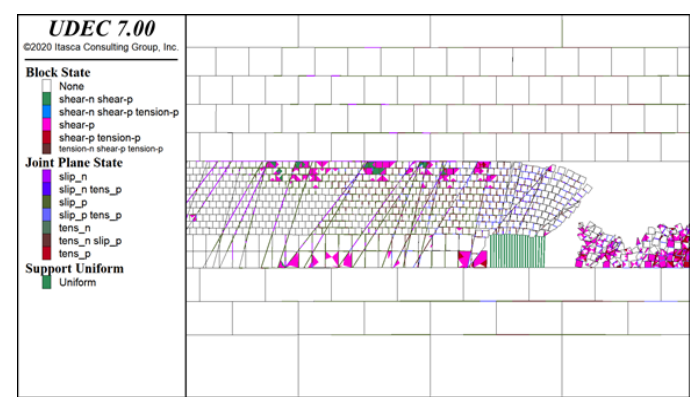

Fig. 9. Calibrated model for studying face spall in longwall extraction

Rys. 9. Skalibrowany model do badania ubytków przodka przy wydobywaniu ścian

One typical feature of longwall extraction is its progressive mining. Therefore, in each mining cycle, coal face is cut by 1 $\mathrm{m}$, followed by the movement of face support, and then the model is run to an equilibrium state. In general, the solution time for a numerical longwall problem may vary from few days to few weeks, depending on the numbers of gridpoints and discontinuities in the model.

\section{Discussion and conclusions}

This paper presents a systematic approach for estimation of coal and rock mechanical properties in the modelling of longwall extraction. Field coal/rock collection, laboratory testing and empirical reduction of material strength are performed to derive input parameters for the simulation. As seen in Table 1, the coal and rock unconfined compressive strengths from Ha lam coal mine are 15.45 and $46.9 \mathrm{MPa}$ in laboratory scale. These values are similar to those reported by Vinacomin Industry Investment Consulting Joint Stock Company (2013) (VIMCC), which are 19.15 and $43.1 \mathrm{MPa}$, respectively. For Vang Danh coal mine, the coal and rock strengths are 26.89 and $89.39 \mathrm{MPa}$ while those reported by the mine are 29.28 and $57.53 \mathrm{MPa}$, respectively (Vietnam Institute of Mining Science and Technology, 2016). There is also a close agreement in terms of coal strength here, while the difference regarding rock strength can be related to the variation in type and location of collected rock samples. Between the two mines, coal and rock strengths from Ha Lam are 1.74 and 1.91 times less than those from Vang Danh. This comparison supports industrial reports in which longwall face geotechnical incidents in Ha Lam mine occurred more often those in Vang Danh mine. For longwall simulation, coal and rock properties from laboratory scale can be reduced to field scale using empirical factors when confined compression test and/or GSI is unavailable. In such a case, the corresponding model must be calibrated and validated against field observations prior to implementing extraction and making the alteration. This paper provides a simple and efficient approach for reliable estimation of coal and rock properties for numerical modelling of not only longwall extraction but also other underground excavations.

\section{Acknowledgements}

This research is funded by the Vietnam National Foundation for Science and Technology Development (NAFOSTED) under grant number 105.08-2019.09. 


\section{Literatura - References}

1. ALEJANO, L. R., TABOADA, J., GARCÍA-BASTANTE, F. \& RODRIGUEZ, P. 2008. Multi-approach back-analysis of a roof bed collapse in a mining room excavated in stratified rock. International Journal of Rock Mechanics and Mining Sciences, 45, 899-913.

2. COGGAN, J., GAO, F., STEAD, D. \& ELMO, D. 2012. Numerical modelling of the effects of weak immediate roof lithology on coal mine roadway stability. International Journal of Coal Geology, 90-91, 100-109.

3. CONTROLS S.P.A. 2020. Rock mechanics testing equipment [Online]. Available: https://www.controls-group.com/ eng/rock-mechanics-testing-equipment/ [Accessed 12 May 2020].

4. DEISMAN, N., MAS IVARS, D., DARCEL, C. \& CHALATURNYK, R. J. 2010. Empirical and numerical approaches for geomechanical characterization of coal seam reservoirs. International Journal of Coal Geology, 82, 204-212.

5. ELMO, D., ROGERS, S. \& KENNARD, D. Characterization of natural fragmentation using a discrete fracture network approach and implications for current rock mass classification systems. In: ESTERHUIZEN, G. S., MARK, C., KLEMETTI, T. M. \& TUCHMAN, R. J., eds. International Workshop on Numerical Modeling for Underground Mine Excavation Design, 2009 Centers for Disease Control and Prevention, Pittsburgh, PA. 29-39.

6. GALVIN, J. M. 2016. Ground engineering - Principles and practices for underground coal mining, Cham, Springer International Publishing.

7. GAO, F. Q. \& KANG, H. P. 2016. Effects of pre-existing discontinuities on the residual strength of rock mass - Insight from a discrete element method simulation. Journal of Structural Geology, 85, 40-50.

8. HOEK, E. \& BROWN, E. T. 1997. Practical estimates of rock mass strength. International Journal of Rock Mechanics and Mining Sciences, 34, 1165-1186.

9. ITASCA CONSULTING GROUP 2019. UDEC - Universal Distinct Element Code, Ver. 7.0. Minneapolis.

10. LE, T. D., OH, J., HEBBLEWHITE, B., ZHANG, C. \& MITRA, R. 2018. A discontinuum modelling approach for investigation of Longwall Top Coal Caving mechanisms. International Journal of Rock Mechanics and Mining Sciences, 106, 84-95.

11. MCNALLY, G. H. Estimation of the geomechanical properties of coal measures rocks for numerical modelling. In: MCNALLY, G. H. \& WARD, C. R., eds. Symposium on Geology in Longwall Mining, 1996 Sydney. The University of New South Wales, 63-72.

12. MOHAMMAD, N., REDDISH, D. J. \& STACE, L. R. 1997. The relation between in situ and laboratory rock properties used in numerical modelling. Int. Journal of Rock Mechanics and Mining Sciences, 34, 289-297.

13. PIERCE, M., MAS IVARS, D., POTYONDY, D. \& CUNDALL, P. A. A Synthetic Rock Mass Model for

14. Jointed Rock. In: EBERHARDT, STEAD \& MORRISON, eds. Rock Mechanics: Meeting Society's Challenges and Demands, 2007. London: Taylor \& Francis Group, 341-349.

15. SAKURAI, S. 1993. Back analysis in rock engineering, CRC Press.

16. SHEOREY, P. R. 1994. A theory for in situ stresses in isotropic and transversely isotropic rock. International Journal of Rock Mechanics and Mining Sciences \& Geomechanics Abstracts, 31, 23-34.

17. SINGH, G. S. P. \& SINGH, U. K. 2009. A numerical modeling approach for assessment of progressive caving of strata and performance of hydraulic powered support in longwall workings. Computers and Geotechnics, 36, 11421156.

18. STARFIELD, A. M. \& CUNDALL, P. A. 1988. Towards a methodology for rock mechanics modelling. International Journal of Rock Mechanics and Mining Sciences \& Geomechanics Abstracts, 25, 99-106.

19. VIETNAM INSTITUTE OF MINING SCIENCE AND TECHNOLOGY 2016. Investment and mining project for level 0 -:- - 175 Vang Danh site, Vang Danh coal mine. Vietnam Institute of Mining Science and Technology.

20. VINACOMIN INDUSTRY INVESTMENT CONSULTING JOINT STOCK COMPANY 2013. Project on investment and extraction of Ha Lam coal mine for level below -50. Hanoi: Vinacomin Industry Investment Consulting Joint Stock Company.

21. WILES, T. D. 2006. Reliability of numerical modelling predictions. International Journal of Rock Mechanics and Mining Sciences, 43, 454-472.

22. WILSON, A. H. 1983. The stability of underground workings in the soft rocks of the Coal Measures. International Journal of Mining Engineering, 1, 91-187. 


Szacowanie właściwości mechanicznych węgla i skał do numerycznego modelowania eksploatacji
ścian
Rzetelne oszacowanie właściwości mechanicznych wegla i skał w skali polowej jest warunkiem koniecznym do numerycznego mod-
elowania zachowań skał związanych z eksploatacja ścianową. W artykule, opisano systematyczne podejście od gromadzenia danych,
badań laboratoryjnych do wyznaczania właściwości górotworu w celu symulacji eksploatacji ścian, na przykład na dwóch pan-
elach ścianowych na polu weglowym Quang Ninh w Wietnamie. Właściwości mechaniczne sa weryfikowane poprzez porównanie z
opublikowanymi danymi polowymi, wskazujac na bliskie uzgodnienia. Dalej rozwijany jest prosty model numeryczny w celu zade-
monstrowania właściwego wykorzystania uzyskanych danych. Symulacja sugeruje, że stosunek długości modelu do długości wykopu
powinien zawierać się w przedziale 2,5-5; jednoosiowa wytrzymałość na ściskanie, moduł odkształcenia i wytrzymałość na rozciaga-
nie można zmniejszyć odpowiednio o współczynnik 5,0, 2,13 i 2,0; oraz należy przeprowadzić proces kalibracji i walidacji, aby do-
pasować zachowanie ściany na miejscu. Podejście to można zastosować do wyprowadzenia wiarygodnych właściwości górotworu do
numerycznej symulacji podziemnych wyrobisk.

Słowa kluczowe: badanie laboratoryjne, właściwości górotworu, redukcja wytrzymałości, modelowanie polowe 